\title{
Religious plurality and individual authority in the Mahābhārata
}

\section{Introduction}

The emergence of religious alternatives to Vedic ritualism in the centuries around the beginning of the Common Era was an important feature of the larger political and socio-economic transformations that unfolded in this period in India. They appeared around the same time as the establishment of the Maurya empire epitomised by King Aśoka (268-233 BCE) and consolidated during the reign of the Gupta dynasty (350-550 CE). This period was marked by an expansion of agricultural production, trans-regional trade, intercultural contacts and confrontations between North Indian rulers and outside invaders (Greeks, Scythians, etc.), the advent of script, and by new modes of representation (sculptures, inscriptions, etc.). ${ }^{1}$ The intellectual dimension of these processes was mirrored in an enormous production of texts reflecting these changes and offering new forms of knowledge. The pluralisation of religious doctrines and practices in this period was connected to processes of individualisation and new interpretations of religious agency. These resulted in enhancing the primary determination of personhood according to normative social roles (accorded in life-cycle rituals) by opening up new pathways for individuals to strive for their own well-being in this life and the afterlife (see Malinar 2015a). This development was manifested in new interpretations of the conditions of embodied, individuated existence, with the discourses revolving around teachings about the self, ego-consciousness, and various ideas of liberation from the limitations of corporeal existence. New interpretations of karman as a mechanism of retribution that not only works in the sphere of ritual, but also (potentially) applies to all deeds accorded individuals an important role in the production of their own life-conditions. Auto-diegetic narration and life-story emerged as new literary forms, ${ }^{2}$ and the depiction of individuals entertaining their own ideas about the goals of life became a recurrent feature in a range of textual sources. Without necessarily taking recourse to the commonly accepted forms of authorisation (initiation by Brahmanical teachers,

1 For a discussion of some features of what has been referred to as the period 'between the empires', see the essays in Olivelle 2006.

2 For an overview of the development of life-history and autobiographical writing in India, see Malinar 2019.

2 Open Access. ( 2019 Angelika Malinar, published by De Gruyter. (c) BY-NC-ND This work is licensed under a Creative Commons Attribution-NonCommercial-NoDerivatives 4.0 International License. https://doi.org/10.1515/9783110580853-057 
for instance), individuals engaged with the questions of what goal is the 'best' (śreyas), what is the 'highest good' (nihśreyas) or the 'unseen purpose' (adrsțârtha) for which one should strive, and what are the best methods for obtaining this good and stopping the causes of suffering. ${ }^{3}$ Some of them voiced their dissatisfaction with well-established and commonly accepted religious goals and practices, and set forth new interpretations of their own; others promulgated alternative religious-philosophical pathways. When these individuals convincingly argued, enacted, and embodied their tenets, they had the possibility of gaining social acceptance as living proofs of the validity of their ideas, and some of them became teachers and attracted followers. Some of these developments can be traced to dissent and a plurality of views already existing within the established, exclusive circles of Brahmanical learning. However, individuals from outside these circles, such as women, warriors, and merchants, also began to appear in the texts and were presented as formulating their own views on religious goals and practices. While the evidence for these developments does not suggest that the individual as such became the centre of social transactions and intellectual discourse - as is the case in modern individualism - it does point to the emergence of a diversified and proliferating religious field, which gave room to a plurality of religious-philosophical pathways that individuals could adopt. ${ }^{4}$ At the same time, resistance against these developments, and thus against further religious pluralisation and individualisation, can also be detected.

The compatibility of the established norms of social life with the new religious doctrines and their individualised forms of practice varied. The established norms were based on the ritual duties ordained in the Veda and administered by Brahmanical experts, predominantly for householders. In the period under discussion, the household was the primary site of religious practice. Vedic religion did not demand the establishment of permanent structures for public ritual performances, such as permanent ritual altars or temples. Such forms of public institutionalisation began to spread with the establishment of larger kingdoms

3 The discourses about these issues and the spectrum of practices connected to them constitute what could be viewed as 'religion' in the period under discussion and this is what I refer to when using 'religious' or 'religion' in this paper. The general question of the applicability of the modern term 'religion' to classical India cannot be addressed in the context of this paper.

4 In standard theories of modernity, now much debated, the emphasis on the rights and the freedom of the individual and the rise of individualism are seen as features which distinguish modern societies from non-modern ones. With respect to the latter it is maintained that the individual is nothing more than a member and a representative of the social group to which he or she belongs. For an influential application of this view to India, see Dumont 1966. For a general critique of Dumont's views, see Fuchs 1988. For a criticism of the idea that Indian culture lacks a notion of the 'individual', see Malinar 2015a. 
and with the popularisation and patronage of new religious ideas and practices. Ascetic religions, such as Buddhism and Jainism, as well as the monotheistic bhakti religions, were important factors in this process (with new religious sites, such as monasteries, reliquaries, icons and temples). Of key importance in this period was the establishment of the royal household centring on the king as a hereditary ruler of his kingdom and a powerful figure whose status and functions were contested. Some of the new religious ideas and practices were directly connected to kings, who are depicted as either teachers or addressees. Furthermore, the king represented participation in the religious field through his intellectual engagement with various religious-philosophical teachings (debates at his court, involvement in different registers of religious practice, patronage, etc.), through statements and rulings on religious groups and practices, through protection and patronage of various religious groups, and through the selection of his own religious preferences beyond his patronage of Vedic rituals and other religious groups. The inscriptions of King Aśoka (268-232 BCE), and the scholarly debates about his (private?) affiliation with Buddhism while supporting a range of religious groups, point towards this constellation of developments. ${ }^{5}$ Literary texts take up the issue as well, as can be seen in the Mahābhärata epic with its inclusion of various discourses about kingship and of a considerable spectrum of religious-philosophical doctrines and practices. But members of other social groups, such as merchants and women from a variety of social strata, also emerge in this period as supporters and practitioners of the new religious teachings. ${ }^{6}$ This is attested in the epic as well.

In this chapter, I shall discuss the ways in which religious plurality is depicted in the epic and ask which roles individuals assumed in the criticism and re-interpretation of the "transmitted knowledge'7 of the Veda. The epic not only documents individual doubts and opinions but also more fundamental

5 See, for instance, Bloch 1952, Lamotte 1953, Thapar 1961.

6 On the spectrum of Buddhist donors, see Coningham 1995; for the role of women, see Willis 1992; on archaeological and other data for the support of bhakti, see Härtel 1987.

7 This expression is used in the following instead of 'tradition', as it is not only closer to the Sanskrit equivalents (āgama, paramparā, sampradāya) but also highlights the processual character of the creation and administration of an authoritative body of knowledge-practice. The latter is characterised by a concern for stabilisation ('canonisation', forging community) and ensuring its continuing relevance (commentaries, production of new texts, selective re-arrangements of practices, attracting new patrons and audiences, etc.). 'Transmitted knowledge' also points to the situation that it is connected to particular 'textual communities' as well as to a selective acceptance of extant authoritative knowledge traditions and canonical texts by different religious communities. What appears as a fixed canon of Brahmanical authoritative texts is rather a 'Kanonfundus', a corpus of texts used selectively in Hindu religious communities; see Malinar 2011a. 
concerns about how to establish reliable knowledge. This connects the epic with the emerging field of philosophy as a new expert discourse. Some philosophical schools accepted originality as well as the exemplariness of an individual (whether human or divine) as the basis for a religious-philosophical truth claim, championing the idea that the testimony of 'trustworthy persons' should also be accepted as a means of knowledge (pramāna). The formulation of such claims in the epic, as well as in philosophical discourse, sometimes included a rejection of the Veda as the sole authority. As a consequence, representatives of the Vedic tradition viewed the proliferating field of religious individualisation as a characteristic feature of a 'dark age' of confusion and undesirable disorder (the so-called kaliyuga), which calls for counter-reaction. While one can detect resistance to and criticism of pluralisation almost from its very beginning, from about the 5th or 6th century there are explicit efforts to delimit the spectrum of choices and to reassert the authority of the Veda over against doctrines and practices based on the authority of individual teachers. This reassertion culminated in Veda-adherent philosophers like Kumārila Bhața (6th-7th centuries) and Sankara (7th-8th centuries), who advocated a restriction of acceptable authorities and the outright rejection of teachers and teaching traditions not based on Vedic texts. While aspects of this later development have been studied in some detail, ${ }^{8}$ the dynamics of pluralisation and the processes of individualisation in the preceding period, to which these reassertions reacted, need to be studied in a more comprehensive manner. The Mahābhārata is an important document within this historical constellation since it not only attests religious plurality but also the resistance to it.

\section{Negotiating religious plurality in the Mahābhārata}

The Mahābhārata $(M B h)^{9}$ includes not only seminal texts of bhakti-religion, Yoga, and Sāṃkya philosophy, but also various discourses about the authority

\footnotetext{
8 SeeHalbfass 1991, Eltschinger 2012. On the repercussions of the reassertion of Vedic-Brahmanical normativity for the acceptance of ātmatuști, individual choice or preference as the reason for a religious practice, see Davis 2007; for the rejection of the idea of 'following one's desire' (kāmacāra) as a desirable goal, see Malinar 2014.

9 In the following, I deal with the epic from a systematic perspective, referring to the text in its redacted, written form as found in the critical edition. The ways in which the juxtaposition of texts is the result of the textual history of the epic is an issue that cannot be addressed here. While there is no scholarly consensus about the exact date of the epic, its written form can
} 
of transmitted knowledge as well as a broad spectrum of individual voices that each give their ideas and opinions about the 'highest' goal and the best practices for its pursuit. ${ }^{10}$ The wide range of texts is indicative of the fact that the validity of the Veda is no longer taken for granted and that the authority (pramāna) of 'transmitted knowledge' has become a highly contested issue. This is one of the features of the epic that have led scholars to view it as a text that mirrors, as well as addresses, a situation of political and intellectual 'crisis' ${ }^{11}$

At the centre of the religious-philosophical debates depicted in the epic are doubts about what actually constitutes the 'highest good' (śreyas, nihśreyas), the working of the law of karman (the law of retribution), the after-world (paraloka) ${ }^{12}$ and, perhaps most often, what constitutes dharma, a polyvalent term that frames in many instances the negotiation of social norms and religious-philosophical doctrines. The word dharma is used in the epic, on the one hand, as an abstract term with a variety of meanings, such as law, good practice, norm, rule, order, righteousness, socio-cosmic order, or religious-philosophical doctrine. On the other hand, it is used in various specified meanings, such as kuladharma (law of family), rājadharma (law of the king), or mokșadharma (rules regarding liberation). The epic deals not only with the clash of different normative orders but also with the situation in which the following of ordained dharma and 'transmitted knowledge' does not yield the expected results. Some protagonists experience

quite certainly be dated to the period under discussion (2nd century BCE - 4th century CE). For an overview of religious positions documented in the epic, see, among others, Hopkins 1902, Strauss 1911, Sutton 2000.

10 A remark on the sheer quantity of texts we are talking about here may be appropriate. For instance, the part of the twelfth Book dealing with mokșadharma ('right practice [for obtaining] liberation') consists of more than sixty texts (comprising 186 chapters) on religious-philosophical issues (including one long exposition of bhakti to the god Viṣnu-Nārāyaṇa). In addition, there are texts such as the Bhagavadgitā in Book 6, the Anugitā and other texts in Book 14, important discourses in Books 3 and 5, and the instructions in Book 13.

11 For an interpretation of the textual history of the epic as testifying to the intention of restoring the ideological supremacy of Brahmans after they lost influence due to Buddhism (patronised by King Aśoka) and other anti-brahmanical groups, see Holtzmann 1892-95 and Fitzgerald 2006. On the role of bhakti as a new doctrine that claims supremacy through mediating Vedic ritualism with ascetic ideals in order to allow householders to seek liberation, see Biardeau 1981 and Malinar 2007a. At the same time, the epic documents the pluralisation of religious-philosophical views and practices by juxtaposing various teachers and teachings, and depicting conflicts of norms and practices without rigorously suggesting one as the 'best' or the 'final word'. This is illustrated in the collection of philosophical-religious texts included in Book 12. On the scholarly debates about the role of these texts in the history of Indian philosophy, see Malinar 2017a.

12 The concern about what remains of a person after death, if there is an afterlife for the individual, is the major topic of a philosophical discourse at MBh 12.211-212; see Malinar 2017b. 
suffering on a scale that defies the idea that obeying the law results in plentiful rewards. Experiences of injustice cause doubts about, and even disgust (nirveda) with, what one was taught to accept. Individuals are depicted as coping with the tensions between their personal opinions and the social-religious values they have been taught to live by. But intellectual dissatisfaction is also an important reason for doubts and dissent. It is manifest in references to new expert groups, such as the "debaters of proofs" (hetuvādins), and in the depiction of householders brooding over the validity of transmitted knowledge. Furthermore, some epic passages highlight the plethora of ideas and practices advertised by all kinds of people as 'best' as the referential framework of meaning for discussing doubt and confusion. ${ }^{13}$ The epic contains numerous texts in which the Veda and its adherents are criticised, although often for quite different reasons and with an equally broad variety of reactions, ranging from censure to endorsement. At the same time, new doctrines, such as bhakti, are not only propagated in the epic but also countered by calls for 'proper' (Brahmanical) authorisation. Furthermore, the epic narrative and the various didactic tales included in it are populated by a number of highly influential Brahmanical authorities who function as instructors and preceptors of the main protagonists. ${ }^{14}$

13 See, for instance, $M B h$ 12.21, where the 'great ascetic' Devasthāna introduces his view on the matter as follows: '[...] Beings look to this and that Law (dharma) in this and that way at one time and another. [...] Some recommend quiet calm, others vigorous exercise; some recommend neither the one nor the other, and others recommend both. Some men recommend sacrifice, and others recommend renunciation. Some recommend giving, and others recommend receiving. Some others renounce everything and sit still in silent meditation. Some recommend kingship, the protection of all creatures by slaying, shattering, and cleaving enemies and wrongdoers, and others live a solitary life' (12.21.6-9; tr. Fitzgerald 2004, 212). Another depiction of religious plurality is at $M B h$ 14.48.12ff.: 'Is there at all among the dharmas (doctrines about the right practice for achieving the highest goal) one known which one must follow best (anușțeyatama)? It seems to us that the course (gati) of dharma is of different sorts, almost contradictory. Some say that there is something beyond the body, others say this does not exist; some say the non-eternal is the eternal, others say the eternal exists and exists not [...] When the right practice (dharma) is being subject to such disagreement it spreads out in diverse ways. We come to no conclusion here - confused as we are. "This is the best (śreyas)! This is the best!" - thinking like this an ordinary man sets out (to obtain it). For the one, who is convinced of something being the right practice to pursue the (best) goal, worships it always'. For a discussion of this whole passage, see Malinar 2015a.

14 For an analysis of how Brahmanical norms are implemented in the household of some epic heroes, see Malinar 2015b. 


\section{The household as a contested site of religious practice}

The discourses in the Mahābhārata show that religious pluralisation was viewed as potentially threatening to the Veda-ordained ritual duties anchored in individual households ( $g r h a$ ) with extended families (kula, kutumba), in particular when goals and practices were advocated that would undermine the household as the centre of ritual-social transactions. This is true, for example, in the case of ascetic practices (tapas) within the Vedic tradition that developed into the new life-styles of the forest ascetic (vānaprastha) and the complete renouncer (samnyāsin). ${ }^{15}$ These forms of ascetic life are recommended as well as controversially debated in the epic. In addition, there was the new religious goal of 'liberation' (variously called mokșa, kaivalya, nirvāna etc.) from corporeal existence (including that in the heavenly worlds propagated in the Veda) as championed, for instance, in the traditions of Buddhism, Jainism, and Yoga. These traditions call householders to 'houselessness', that is, to becoming itinerant ascetics, renouncers, lonely practitioners, monks, nuns, etc. However, 'houselessness' is not the only form of religious individualisation in this period, as is suggested by the juxtaposition of 'householder' and 'renouncer' as an influential scholarly representation of religious life in classical India. ${ }^{16}$ We also see householders expressing their own views and engaging in new religious ideas and practices without showing any intention of changing their status or leaving their family in order to follow a particular religious doctrine. The new religious doctrines offered not only 'renunciation' but also various other forms of engaging with the 'highest' goal of liberation, such as providing support for mendicants, or performing devotional reinterpretations of daily activities.

It was not only Buddhism that offered householders new avenues for engaging in religious-philosophical knowledge (monasticism, becoming a lay follower) but also the new monotheistic bhakti doctrines promulgated in the epic in texts

15 For the history and institutionalisation of samnyāsa and the gradual acceptance of 'liberation' as a 'goal of men' (purușārtha) in addition to the classical three goals of Vedic ritualism, see Olivelle 1993.

16 This juxtaposition has been discussed variously in connection with Louis Dumont's claim that the renouncer represents 'the individual-outside-the-world' (Dumont 1981); see also above footnote 4. While this juxtaposition has served to address certain features of Indian society, the actual scope of agents and life-styles in classical sources needs to be dealt with, a factor which complicates matters considerably. 
such as the Bhagavadgitā (BhG) and the Nārāyañiya. ${ }^{17}$ These emphasise the compatibility of a householder life-style devoted to god with the prospect of liberation, and they redefine 'renunciation' (samnyāsa) as dedicating, 'giving away' one's daily activities to god, and 'liberation' as a state in which the devotee shares or gains access to god's transcendent state of being. Furthermore, Buddhism as well as bhakti doctrines advocate renunciation as an option for all (and not only for male initiates of the Veda) and they include in religious activities householders, such as women and Sūdras, who were previously excluded from learning Vedic texts or practising Vedic rituals on their own. In this way, they considerably widened the spectrum of potential followers. ${ }^{18}$ Vedic ritualism was thus not only challenged by the new ascetic religions but also by householders who were attracted by the new forms of practice (temple worship, giving alms to monks, nuns etc.) and who had their own ideas about god(s), the after-world, and the best religious practice. One important feature of this plurality is that doubt and confusion about which religious goal and practice are the best are depicted and discussed in the epic as well. This suggests a situation in which religious authority has ceased to be based exclusively on patterns of kinship, well-established genealogies of social relationships, and restricted access to Vedic texts handed down exclusively by Brahmanical teachers. Instead of paying heed to the Veda transmitted from time immemorial, new teachers promulgated their own doctrines and practices without necessarily seeking Vedic authorisation. Furthermore, representatives of Vedic ritualism are accused of a lack of 'true' knowledge and of abusing rituals for dubious, egotistical purposes, with these representatives or their clients said to be guilty of perverting the true meaning of sacrifice. ${ }^{19}$ They are also criticised for asserting that there are no alternatives to the goals and practices of the Veda (nānyad asti: 'there is nothing else'). ${ }^{20}$ This criticism is often connected with doubts about the basis of authority (pramāna / prāmānya) and thus points towards the changing modes of authorisation for religious texts and practices, which now seem to include individual experience and testimony.

17 For an analysis of the $B h G$ and its relationship to the epic discourses, see Malinar 2007a; for the Nārāyaṇiya, see the essays in Schreiner 1997.

18 See, for example, the authorisation of women and Sūdras for practising bhakti at BhG 9.32. This targeting of the lower classes is viewed by the critics of these developments as a flaw of the new teachers and as a dubious strategy to attract followers; see, for instance, epic and purānic depictions of the present age of decay (kaliyuga) in which Sūdras become teachers; see Eltschinger 2012; for similar statements in philosophical texts, see Halbfass 1991.

19 Such criticism is not only voiced in texts like the $B h G$ (for instance BhG 2.40-3, and 16.10-7) but also by representatives of Brahmanical norms themselves. See for instance $M B h$ 5.43.31.

20 This is how the opinion of those engrossed in expounding the Veda is summarised at BhG 2.42. 


\section{Doubting the reliability of transmitted knowledge}

When epic protagonists are faced with divergent views and contradictory injunctions, reasoning and critical inquiry are presented as means for resolving the difficulties, although this is not always accepted unanimously. While critical examination is in some instances recommended as a method for establishing what can serve as a guideline and authority in matters concerning the 'highest good', it is elsewhere viewed as the cause of all intellectual problems and the weakening of age-old authorities. Not only new expert groups, such as the 'debaters of proofs/reasons' (hetuvādins), are depicted as reasoning about the validity of transmitted knowledge ${ }^{21}$ but also individual protagonists. The latter are presented as voicing their doubts when faced with theoretical and practical dilemmas that result in a critique of the social role they ought to represent and of the use of 'playing by the rules'. One important aspect of the depiction of these views is that the social basis for producing and obtaining religious knowledge is enhanced through the depiction of Kṣatriyas and Vaiśyas as authorities in religious matters, a role that is no longer restricted only to Brahmans. Women are also depicted as using ritual instruments on their own, ${ }^{22}$ as practising forms of religion not envisaged for them, ${ }^{23}$ and as doubting the validity of established religious doctrines.

An example of the latter is the dialogue between Queen Draupadi and her husband King Yudhișțira at Mahābhārata 3.28-37. The couple discuss the reasons for following prescribed dharma when this does not produce the promised

21 In quite a few places, the 'debaters of proofs' (hetuvādins), who attack the Veda and Brahmanical norms with the 'science of reasoning' (tarkavidyā) are accused of excessive doubting and of propagating disregard for transmitted Vedic knowledge. In one of the more elaborate polemics, they are compared with dogs and condemned as being unsuited for social relationships (MBh 13.37.11-6). Elsewhere, their appearance is interpreted as a sign that the last and worst of the four world-ages, the age of decay (kaliyuga), is in full swing ( $M B h$ 3.188.26). On the relationship between such 'heresy' and 'apocalyptic' ideas in later Purānas and in Buddhist literature, see Eltschinger 2012.

22 See the two versions of the story about how Kuntī obtained a powerful mantra that allowed her to summon any god she desired at $M B h 1.104$ and 3.287-289; in relation to this incident a discourse unfolds at 1.111-3 that aims at prohibiting the independent agency of women; see Malinar 2014.

23 At $M B h$ 9.51, the Brahman sage Nārada objects to the unlicensed ascetic practices carried out by the daughter of the Brahman Kuni-Gārgya and forces her into marriage, since unmarried women are not allowed to become ascetics. On the epic depiction of Nārada as a representative of Brahmanical normativity, see Malinar 2015b. 
rewards but, rather, only disaster. ${ }^{24}$ Draupadì says (3.31.7): 'The Law, when well protected, protects the king, who guards the Law, so I hear from the noble ones, but I find it does not protect you'. She calls on her husband, who has lost his kingdom despite always obeying dharma, to accept that such obedience does not work and to stand up and fight for his rights. She also suggests that the karman doctrine that implies 'good will do good' is in fact an idea disproven by the sad reality of the exile she and her husband are suffering. For the learned (pandita) Draupadi, the ideas of 'order' and 'justice' implied in the terms dharma and karman have become dubious. She suspects that it is not lofty values that count but only actual power (bala): 'Or, if the evil that has been done does not pursue its doer, then mere power is the cause of everything, and I bemoan powerless folk!' (MBh 3.31.42. tr. van Buitenen 1975, 281). She also argues that the gods are mere schemers who are not interested in human welfare but rather treat human beings like puppets (3.31.35-7). Yudhișthira is alarmed by the critical impact of her reasoning, of her doubting that transmitted knowledge is the authority (pramanna) in salvific matters. He seeks to censure what he views as a transgression and accuses her of being a 'non-believer' (nāstika) since she doubts and argues too much. ${ }^{25}$ He warns his wife of the negative karmic consequences (being reborn as an animal) of her denying established authority. She is accused of àtmapramāna, of taking herself (ātman) as authority, instead of relying on ärșapramāna, on the authority derived from the Vedic sages (rși). Says Yudhișthira: 'Who is excessively doubting dharma will not find a means of knowledge (pramāna) in anything else. Arrogant is he who takes himself as the authority (ätmapramāna) as he despises what (or: who) is superior. [...] Who neglects the authority that belongs to the sages (ārșam pramānam) is not guarding the laws, being deluded he violates all authoritative instructions and does not find any peace in all his lives. You must not doubt excessively the dharma that is followed by the learned as it is timeless (old), being proclaimed by all-knowing, all-envisioning sages' ( $M B h$ 3.32.15, 20-1). Individual, self-reliant reasoning is checked here by insistence on belief, on the (tautological) statement that one must follow the ancient truths because one should better not doubt them. The excessiveness of the criticism is presented

24 For an analysis of the whole dialogue focussing on the issue of gender, see Malinar 2007b. Another royal household debate at $M B h 12.18$ concerns a king who has chosen to live from alms (bhaikșya) after taking up the life-style of a 'skull-bearing' ascetic (kāpālīm vṛttim). His wife reprimands him for what she thinks is mere hypocrisy.

25 See the many occurrences of the prefix 'ati-', signifying an excessive or deviant performance of the activity denoted by the verb. Thus, Draupadi is said to 'doubt too much' (ati+śank, 32.6, $7,9,14,15,17,21)$, to 'argue too much' (ati+vad, 32.6), to 'transgress' (ati+gam, 32.9.20) and to 'offend' (ati+vrtt, 32.18) norms. 
as the main reason for Yudhișthira's warnings as it results in Draupadī claiming a position she is not entitled to; at least not according to the very norms she objects to.

In Book 12 of the epic, Yudhișthira's own questions about dharma are made the point of departure for a series of discourses. At several points he is depicted as doubting transmitted knowledge. At Mahābhārata 12.251-2, for instance, Yudhișthira asks his grandfather and teacher Bhīṣma about the criteria for defining dharma. Initially, Bhīṣma answers rather conventionally (following the account in Dharmaśāstra literature) by stating that dharma can be defined by reference to sadācāra, the 'conduct of the good (norm-setting) people' or 'good (norm-setting) conduct', to authoritative dharma texts (smrti), and to the Veda (veda). But Yudhișțira's doubts are more fundamental when he turns to logical reasoning (anumāna). He detects contradictions, circular reasoning, and other undesirable characteristics of the three conventional methods of authorising dharma. First of all, Yudhișțhira takes up the 'conduct of good (norm-setting) people' (sadācāra) and points out that it suffers from the flaw of 'mutual dependency' (anyonyasamśraya, circular reasoning): 'Dharma is regarded as the practice of the good, if however good people define what is (good) practice - how can one prove what needs to be proved, since what is good remains undefined?' (MBh 12.252.5). Thus, good practice cannot be used as a criterion for defining dharma because it is explained by reference to undefined 'good people'. ${ }^{26}$ Next, the reliability of the authority of the Veda and (Veda-based) dharma manuals is questioned by pointing out that 'the doctrines of the Veda diminish from world-age to world age' (12.252.7) and that the Veda is 'spread out in different directions' (12.252.9). The diversification of the Veda entails the possibility of contradictory injunctions and thus undermines the reliability of these texts in matters of dharma. ${ }^{27}$ Therefore, they cannot serve as a pramāna, an authority, a means of knowledge: 'If they [the different texts] were all a means of knowledge (pramāna) then a means of knowledge would not be available at all. How then is scriptural authority established in case of contradiction, when it is both a means of knowledge and not a means of knowledge?' (12.252.10). Once the problem of defining the authority of transmitted knowledge has been recognised, certainty vanishes like a mirage as soon as it is explored by

26 On this problem and the definitions of ācāra in medieval Dharmaśāstras, see Davis 2004. Yudhișthira further rejects the method of inferring dharma from its opposite (adharma) and vice versa.

27 Diversification refers, on one hand, to the transmission of the canon of the 'four Vedas' (caturveda) in different schools, and, on the other, to the very pluralisation of the original single (eka) Veda into four; see Malinar 2011b. 
'critically examining thinkers' (anvīkșyamāṇạ̣ kavibhiḥ; 12.252.13). This loss of old certainties is an important point of Yudhișțira's speech.

How is this reasoning dealt with here? Instead of demonstrating in which respects the Veda can be regarded as pramāna, or arguing that erudite Brahmans set the standard for what should be taken as the 'practice of good people', Bhīsma gives an account of an encounter between the merchant Tulādhāra, belonging to the Vaiśya caste, and the Brahman Jājali (MBh 12.253-256). At the beginning of his account Bhīsma relates that Brahman Jājali, a great ascetic dwelling in the forest, went to the ocean for further ascetic practice (tapas). When he began to think that there was nobody to equal him, he was told by the Piśācas (forest demons, goblins) surrounding him that he ought not entertain such thoughts. Such thoughts, they said, are not appropriate even for the famous merchant Tulādhāra in Varanasi. A displeased (vimanas) Jājali exclaims that he wants to see this man and sets out to pay him a visit. At this point Yudhișthira interrupts the account and asks what Jājali did in order obtain such high ascetic perfection (siddhi). Bhīṣma replies (12.253.13ff.) with a second report of what brought the Brahman to Varanasi. ${ }^{28} \mathrm{He}$ relates that Jājali had been following the rules of forest asceticism all on his own and was engaged in 'terrible' (ghora) ascetic exercises (tapas). For years he would sit like a piece of wood, 'eating wind', and letting a pair of birds build a nest on his head. Since he did not move, the birds were not afraid to lay their eggs and raise their offspring on his head. When the birds finally left, Jājali was amazed by his own achievement: "He thought "I am a Siddha (a perfect man)" and selfconceit (māna) possessed him' (12.253.38). He blurted out his conviction that he had mastered dharma (12.253.41). However, in response to this Jājali was immediately rebuked by 'a voice in the air' stating that in matters of dharma he was not the equal of the wise Tulādhāra - and even Tulādhāra was not permitted to talk like this. Full of anger, Jājali travelled to Varanasi and approached the merchant, who was going about his business. When Tulādhāra, 'who made his living from merchandise', saw the Brahman he welcomed him by displaying his knowledge about Jājali and about the circumstances that brought him to Varanasi. Mocking the Brahman slightly, he pointed out that the latter believed that mastering dharma consists of 'taking care of sparrows' and this misconception is the reason why Jājali was directed to him.

The Brahman then asks how Tulādhāra, a merchant (vāṇija) dealing with all kinds of goods, has obtained the 'highest insight' (naișthiki buddhi). ${ }^{29}$

28 A discussion of the composition and textual history of the Tulādhāra story is beyond the scope of this chapter. Both accounts highlight the problem of individual ascetics misjudging religious achievements (see also below).

29 Thisexpressionisusedalsoin otherinstancesin theepicfor perfectionin religious-philosophical knowledge; see for instance, $M B h$ 12.211.15; 217.28; 260.8. 
In introducing the merchant's reply, Bhīṣma highlights the rather unusual situation that the Brahman is taught 'subtleties of dharma' (dharmasūkșmāṇi) by a Vaiśya, who knew the true meaning of dharma (12.254.4). Without further ado, Tulādhāra starts his instruction by pointing out that to live one's life without bearing malice towards anybody is the dharma that is eternal, ensures the welfare of all beings, and is friendly (maitra). In putting this into practice he has chosen 'sameness' (samatva), being impartial, as his religious observance (vrata), which he practises not in the context of Yoga mediation or other ascetic practices, but in his daily transactions with his customers. He describes his trade and points out that he holds his 'scales' (tulā) the same for all alike. ${ }^{30}$ Irrespective of whether they are friends or enemies, whether he weighs gold or grain: all are his friends whom he wishes well. Says Tulādhāra: 'He who is the friend of all, and is always delighted in the welfare of others in deeds, thoughts, and word, knows dharma, Jājali. I neither praise nor condemn the deeds of others as I am watching the colourfulness of the world like [I watch the clouds] in the sky. I neither coax nor impede, ${ }^{31}$ neither hate nor love. I am the same towards all beings, behold, Jājali, my observance! [...] My scales are the same for all beings' (12.254.9-12). Furthermore, the merchant points out that not posing a danger for others is the best conduct ( $\bar{a} c \bar{a} r a)$ and therefore any maltreatment of animals (in trade, agriculture, or animal sacrifice) and human beings must be avoided. Otherwise, one takes what is not authoritative (apramāṇa) as an authority (pramāna; 12.255.14). Impartiality and non-violence set the highest standard of dharma which others (namely: Vedic Brahmans, ascetics, and mighty people) have ruined through violent partisanship (12.254.21).

The scales are both instrument and yardstick for Tulādhāra's understanding of dharma as a steadfast 'observance' of 'impartiality'. His way of carrying out his profession is depicted as a religious practice that sets a standard for the 'conduct of good people' and also for Brahmans. The issue of what constitutes 'conduct of good (norm-setting) people', and thus 'good (norm-setting) conduct' (sadācāra), raised earlier by Yudhișțira's identification of the lack of a definition of what or who is 'good' (sat), is here addressed by means of a didactic story. The Tulādhāra story has received some attention for its advocacy of non-violence (ahims $\bar{a})$ and

30 The name Tulādhāra (meaning 'scales-holder') seems programmatic for this convergence of professional life and religious practice.

31 This can be very well understood as referring to his non-manipulative handling of the scales (see also the use of the âtmanepada form of the verbs in this stanza). 
its criticism of animal sacrifice. ${ }^{32}$ But the merchant's ideas about sama(tva), being 'the same', 'impartial', 'indifferent', as the best practice is also an important aspect of the text. It is presented as a form of conduct in which Tulādhāra's personal engagement with religious-philosophical knowledge converges with the professional activities of his daily life. However, it is not depicted as resulting from an affiliation with a specific religious tradition or community. This resonates with other epic passages in which samatva, 'sameness' or 'impartiality', is advocated as a desirable attitude that demonstrates a person's freedom from egotistical interests (rooted in desire, anger etc.) and his concern for the welfare of others. ${ }^{33}$ But it is also presented as the result of meditative practices in the context of specific religious-philosophical teachings, such as Yoga, Sāṃhya philosophy, and bhakti. ${ }^{34}$

The depiction of the merchant Tulādhāra's idea of 'sameness' resonates with the uncertainty Yudhișthira had voiced earlier with respect to the criteria which establish the validity of Vedic texts and define what is 'good' norm-setting conduct. His ideas of dharma are put into practice as an 'observance' (vrata) that is tested in the merchant's daily business of 'holding the scales' for all kinds of people. The merchant's views and his criticism of Brahmanical norms and practices are neither challenged nor explicitly endorsed, apart from their being reported by Bhīṣma to Yudhișthira. In contrast to this, Jājali's solitary pursuit of asceticism results in a misunderstanding of dharma ${ }^{35}$ which is connected in

32 See Proudfoot 1979. The Tulādhāra instruction is not the only text in the epic advocating non-violence as the yardstick of what is a salvific, norm-setting practice irrespective of the religious path adopted; see, for instance, $M B h 14.48 \mathrm{ff}$.

33 For instance, $M B h$ 12.152.30; 12.154, 12.161.42.

34 The Bhagavadgitā, for instance, recommends Yoga as a method of becoming 'the same', which entails being able to view all things and beings as same, and to see the 'same' (absolute being, here: the self, ātman) in all beings; see, for instance, BhG 2.48, 4.22, 5.18-9, 6.8-9, $29,32$. In connection with its bhakti teachings, 'sameness' is described in the same text as an attitude of the highest god towards all beings. It is declared that the god Vāsudeva-Kṛṣna is not only 'neutral' (udāsīna), that is personally disinterested in engaging in earthly matters, but also impartial (sama), since he himself treats all beings alike, without personal aversion or affection. Yet, this impartiality is scaled since he responds favourably to those who approach him with bhakti; see BhG 9.29-32; for a scaling of different forms of bhaktas, see BhG 7.16-28 and for an evaluation of different ascetic practices vis-à-vis bhakti, see BhG 12; samatva is also propagated as a characteristic feature of a devotee, for instance at 18.54; see Malinar 2007a.

35 This is not the only instance in the epic in which a Brahman ascetic is criticised for his misunderstanding of dharma by 'inferiors', such as a wife or a member of a lower caste. At $M B h$ 3.197, for instance, the Brahman Kauśika is first criticised by his wife for his ascetic life style and then by a hunter; see Brinkhaus 1994 for the composition of the text. In a similar vein, when Yudhișthira entertains the idea of becoming a forest ascetic (12.9), he is criticised by his brothers (12.18ff.). 
the text to the situation when a person takes himself as the authority for validating his or her own achievements. This points to a problematic aspect of religious individualisation, namely the danger of misjudging and misinterpreting religious ideas and practices when pursuing them on one's own. The case of Jājali illustrates the danger of being carried away by achievements deemed extraordinary such that one comes to thinks that one's achievements are incomparable. The case of Draupadi points to the problems that arise when confidence in transmitted knowledge dwindles. Her experience of injustice results in a transgression of social roles and normative religious behaviour when she claims the right to think for herself, to take herself as the authority (ātmapramāna). In contrast to Jājali, Draupadī is censured by her husband as he keeps his dharmic faith. This highlights the gendered structure of the individualisation processes and the authorisation of individual agency as depicted in the epic. ${ }^{36}$ While both instances demonstrate that disapproval and censorship are never far away, it is also made clear that the querying of dharma, 'higher' insight, and norm-setting conduct is no longer the exclusive possession of Brahmanical authorities and that the discourse is not limited to negotiating the relationship between asceticism and householder-life.

Not only in the passages discussed before, but also elsewhere in the epic, the word pramāna serves frequently to address the issue of authority, and in some instances, it seems to be already imbued with the new technical meanings in philosophical expert discourse, 'means of knowledge' and 'valid cognition'. The newly emerging field of philosophy is an important arena for negotiating and delimiting religious pluralisation and individualisation in this period. The rise of philosophy is part of the cultural-historical context of the epic debates on authority. ${ }^{37}$ It plays an important role in the consolidation of old and new fields of knowledge in authoritative bodies of texts (śāstra, sūtra etc.), in the delimitation of ideological pluralisation, and of individual authority in matters pertaining to the 'highest good'. In the following, some aspects of the philosophical discourse on valid knowledge shall be highlighted that connect the epic debates to another field of discourse which deals with ideological pluralisation and the broadening of the social basis of people engaged in religious-philosophical issues (royal households, merchants etc.).

36 This issue cannot be discussed further within the scope of this chapter; see Malinar 2007b, 2014. 37 For a discussion of the place of philosophy in the epic in the history of Indian philosophy, see Malinar 2017a. 


\section{Trustworthy persons as 'means of knowledge' in philosophical discourse}

Individual statements about the 'highest good' and debates about their authority are represented in the epic without rigorously expounding one religious-philosophical pathway as 'the best'. The epic juxtaposes various texts that claim to provide instruction about the 'best' and even places some of these at nodal points in the epic narrative, as if launching an ideological key-text. However, none of these positions is endorsed or activated across the epic as the religious-philosophical 'master-discourse' ${ }^{38}$ While the epic testifies to ideological pluralisation, philosophy is one of the driving forces of religious-philosophical pluralisation and at the same time provides instruments for regulating it. Philosophers cope at an epistemological level with the validity of competing religious-philosophical doctrines, inter alia, by making 'doubt' (samśaya, śankha) a prerequisite as well as a topic of philosophical expert discourse. Even more important is that critical inquiry and ensuring the validity of knowledge through accepted 'means of knowledge' become the characteristic features of philosophical discourse. In this connection, the word pramāna (in epic often used in the sense of 'authority', 'yardstick', etc.) obtains new technical meanings, namely 'means of knowledge' and 'valid cognition'. ${ }^{39}$ The production of philosophical tenets also entailed teachings not based on the Veda or even critical of it. Philosophers like Kapila, the founder of Sāṃhya philosophy - which in its systematic exposition declares that the Vedic soteriology is 'uncertain' (anekānta) -, were accepted as authorities, a status that had to be validated. This meant not only justifying the criticism of the Veda but also providing criteria for the authority of the words of an innovative philosopher or religious teacher who was not transmitting or reinterpreting the 'eternal' Veda. The crisis of the authority of the eternal 'words' of the Veda and the claim that newly promulgated dharma is also reliable, or even more reliable, are addressed in philosophical discourse with the acceptance of the

38 Various candidates for such an ideological 'master-discourse' have been suggested (for instance, Sāṃkhya philosophy, bhakti, Brahmanical normativity) without reaching a scholarly consensus; for an overview of the debates on 'philosophy' in the epic, see Malinar 2017a; for various interpretations of the epic, see Brockington 1998.

39 The two meanings of pramāna point to what Matilal calls the 'systematic ambiguity' of the term that 'means both, a means for (or a way of) knowledge and an authoritative source for making a knowledge-claim. It also means a 'proof', a way of proving that something exists or something is the case' (Matilal 1986, 35f.). 
verbal testimony (vacana, śabda) of knowledgeable individuals ('trustworthy persons', apta) as a means of knowledge on a par with the Veda. ${ }^{40}$

The ensuing philosophical debate on the reliability of the 'statements of trustworthy persons' (aptavacana) testifies, on the one hand, to attempts to legitimise new teachers and doctrines, and, on the other, to a resistance to further pluralisation and individualisation of teaching traditions. The latter is mirrored in the arguments against the authority of individuals in matters of 'unseen goals' and 'highest good' offered by Mīmāmsā philosophers championing the sole authority of the Veda. The controversy is based on a general consensus among philosophers, who accepted 'verbal testimony' as a means of knowledge, that without words there would be no knowledge about things and entities that are invisible (adrsțta), such as the after-world (paraloka) and the 'immortal self' (ätman). The other means of knowledge, perception (pratyakșa) and logical inference (anumāna), cannot provide such knowledge. According to Nyāya philosopher Pakṣilasvāmin Vātsyāyana (ca. 5th century), a trustworthy person gives instruction (upadeśa) in invisible goals (adrștārtha) one should strive for, and also provides the reasons (hetu) for the recommended course of action. In his commentary on the Nyāyasütra he states: "“Trustworthy persons" ${ }^{41}$ are those whose characteristic feature is to perceive directly "this must be abandoned", "this is the reason for abandoning it", "this is something that needs to be obtained", "this is the reason for obtaining it", 42

In philosophical discourse, aptavacana is treated as a source of philosophicalreligious knowledge as well as an object of philosophical examination. Reasons must be adduced and the knowledge derived from verbal testimony is open

40 The acceptance of verbal testimony or knowledge derived from words (śabda) as a pramāna side by side with perception (pratyakșa) and logical inference (anumāna) is a characteristic feature of Indian philosophical discourse. Most philosophical schools accept 'verbal testimony' as a pramāna; exceptions are the materialists (who have no use for 'invisible goals'), and early Vaiśeșika; for an overview, see Saksena 1951, Oberhammer 1974, and Malinar 2013. While the 'words of the Buddha' (buddhavanaca) are the basis of Buddhist practice, the question of in which respects the Buddha was regarded as a pramāna by contemporary Buddhist philosophers Dignāga (ca. 5th century) and Dharmakīrti (ca. 7th century) is intensely debated by scholars; see, for instance, Ruegg 1994 and 1995, Krasser 2001, and Silk 2002.

41 The plural form āptāh can also be understood as an honorific 'the trustworthy person'.

42 āptāḥ khalu sākṣātkṛtadharmāṇaḥ idaṃ hātavyam idam asya hānihetur idam asyādhigantavyam idam asyādhigamahetuḥ iti; Nyāyabhāșya on Nyāyasūtra 2.1.68. The Buddhist logician Dharmakīti states: 'Man cannot [safely] exist without resorting to the [reliable] authority of tradition [consisting of reliable statements], because from [reliable verbal knowledge, àgama, alone] he hears the great advantage and the [great] disadvantage of engaging in or abstaining from certain [acts] whose results are not [at present] perceivable' (Pramānavarttikasvavrtti, 108, 2-5, tr. van Bijlert 1989, 119). 
to critical examination by means of the other pramannas (perception, logical inference). ${ }^{43}$ How does one know that a person is 'trustworthy' and his instruction reliable? Philosophers who accept the authority of the statements of trustworthy persons (aptavacana) argue that the exceptional qualities of these individuals are the criteria for their authority in these matters. Nyāya philosophers emphasise that the instructions by trustworthy individuals are based on immediate 'insight' and 'direct perception' - much the same as with the Vedic sages $^{44}$ - and on the desire to communicate it truthfully. ${ }^{45}$ Another feature regularly mentioned in these discussions is that such a teacher has 'compassion' or 'empathy' (anukampa, karunāa) for those who are not capable of knowing on their own how to obtain the 'highest good' and end their suffering. ${ }^{46}$ This characteristic is closely connected to the claim that, in contrast to ordinary persons, trustworthy teachers are free from egotistical impulses (desire, hate, etc.) and have nothing to gain for themselves when they instruct others. ${ }^{47}$ Therefore, they are also not liable to lie and cause deception because such misdemeanour only occur if personal interests are pursued. In cases of the 'trustworthy', lying would not serve any purpose. ${ }^{48}$

43 This is the position Pakșilasvāmin Vātsyāyana when he states: 'The self exists - this is known from the instruction by a trustworthy person'. He then continues with the logical inferences (anumāna) that would support and substantiate the validity of the verbal testimony; cf. Nyāyya-sūtrabhāṣya on Nyāyasūtra 1.1.1.

44 In accordance with a widely accepted notion that certain persons are able to directly perceive the things that are beyond the senses, early Nyāya texts claim that the founder of the science of medicine (Āyurveda) had direct knowledge of all diseases and cures. Similarly, the seers of the Veda have directly perceived how the Vedic texts are connected to rituals and their results, see Chemparathy 1983. Yāska's Nirukta 1.20 stresses the ability of the rsis to perceive dharma directly, while later generations lack it: 'There were seers who directly perceived dharma(s). By [their] instruction they transmitted the [Vedic] mantras to the later ones, who did not directly perceive dharma(s)' (tr. Ruegg 1994, 308).

45 Pakșilasvāmin Vātsyāyana, for instance, explains: 'A teacher (upadeșțā) who has directly perceived dharma and is motivated by the desire to communicate the matter as he has seen it and is capable to do so, is "trustworthy" (äpta)'. Nyāyabhāṣya on Nyāyasūtra 1.1.7.

46 See Nyāyasūtrabhāṣya on Nyāyasūtra 2.1.68, which resonates with Buddhist as well as early bhakti texts.

47 In a similar vein, but with an emphasis on the trustworthiness of the statement itself, the author of the Yuktidipika and philosopher of Sāmkhya explains: “Trustworthy” (äpta) is the utterance of someone who is free from passion etc.; it serves the purpose of another and is the cause [for a cognition] that cannot be obtained [with other means of knowledge]' (āptā nāma rāgādiviyuktasyāgṛhyamāṇakāraṇā parārthā vyāhṛtiḥ, YD on Sāṃkhyakārikā 5, 87, 4).

48 The alternative would be to keep one's insights to oneself and just pursue an individually discovered truth privately. This option is a topic, for instance, in the case of the Buddha when he is depicted in the Pali Canon as being reluctant to teach after he has awakened to the "noble 
Exponents of the Veda rejected these views and argued that only the words of the Veda are reliable since they are by definition 'unalterable' (akșara) 'truth-formulations' (brahman) that were 'seen' and then voiced by ancient sages (rși). This position is elaborated in the philosophical school of Mīmāmsā by means of the doctrine of the 'authorlessness' (apauruseyatva) of the Veda (so-called śruti). Philosophers such as Kumārila Bhațta refuse to accord individualised truth-claims a status on a par with the Veda. ${ }^{49}$ At the most, they would accept them as smrti, less authoritative texts composed by human authors. Mīmāmsā philosophers argue that human beings are not reliable as they are subject to egotistical impulses and therefore prone to errors. This makes their words structurally unreliable. This argument also applies to 'eternal' persons, that is bhakti gods, such as Vāsudeva-Kṛṣna, or (later divinised) philosopher / teachers, such as Kapila or the Buddha, since they need a body (the site of egotistical impulses) in order to instruct people about dharma. Mīmāmsā philosophers would also not accept the claim formulated in bhakti texts and endorsed by later Nyāya philosophers ${ }^{50}$ that the 'highest' god is the creator of the Veda. In this respect, the Bhagavadgit $\bar{a}$ and the Nārāyaṇiya, the early bhakti texts transmitted in the epic, differ from later theological-philosophical justifications of bhakti that seek to prove that their texts and practices are rooted in the Veda (vedamūlatva). These developments demonstrate that the religious pluralisation in the period under discussion does not simply continue. Instead, we see a reassertion of Brahmanical normativity that, inter alia, aimed at restricting a further proliferation of religious individualisation in the context of bhakti and other religious traditions.

truths', as well as in the figure of the pratyekabuddha (Pali: paccekabuddha), the Buddha who is a Buddha for himself only; see Kloppenburg 1983. See also MBh 12.9.3ff. on the attractiveness of solitary asceticism as the 'blissful' path one travels all alone.

49 As is emphasised, for instance, by Taber 1992, 205: 'Mīmāṃsā fundamentally rejects the ability of humans to know any transcendent matters'. This also applies to the idea that the Veda is created by (an) iśvara (creator god, god as cosmic sovereign) as propagated in some of the monotheistic bhakti traditions; see also Clooney 1987, who includes modern ideas of 'authorlessness' in his discussion of this position.

50 Later Nyāya texts, such as Udāyana's Nyāyakusumāñjali (10-11th century), defend the authority and validity of scripture and verbal testimony (including the Veda) by arguing that it was produced and promulgated by the eternal creator god (î́vara), thus rejecting the Mīmāmsā doctrine of the 'authorless' eternity of Veda; see Chemparathy 1972. 


\section{Trustworthy 'eternal' persons in the epic}

As in philosophical discourse, the reliability and authority of the words of an individual is depicted in the epic as depending not only on the reasons provided for recommending a certain doctrine but also on the qualifications of speaker. Thus, epic texts emphasise the speaker's disinterestedness and his freedom from 'desire and anger'. Compassion (anukampa) and the concern for 'the welfare of all beings' (sarvabhütahita) serve as credentials. In addition to this, the personal relationship between the teacher (revealing his divinity in the course of the instruction) and the person approaching him plays a prominent role in the two longer epic instructions about bhakti. The 'conversation' (sampvāda) between two individuals constitutes not only the narrative situation but also the form of instruction. ${ }^{51}$ The authorisation of the instruction is connected to a personal relationship based on acceptance and trust. ${ }^{52}$ This is highlighted, for instance, when audiences are asked to have śraddha , confidence in the efficacy of a doctrine, because of the authority of the teacher.. ${ }^{53}$ The trustworthiness of the teacher is mirrored by the trustfulness of the suitable disciple. ${ }^{54}$ Trust plays an important role in the process of establishing the authority of individual-based religious-philosophical knowledge, since it is intrinsically connected with the relational character of authorisation. The confidence in the goals and practices taught by the teacher must be stable in order to ensure one's success. This means 'keeping the faith' even in situations that seem to disprove it, or when one is censured by others. The emphasis on the actual teaching situation is thus an

51 In this respect, these dialogues differ from the collective discussions in household contexts as the arena for voicing opinions and giving advice. See, for instance, the household discussion about Yudhișthira's wish to give up kingship and become an ascetic at MBh 12.6-38; or the deliberations about war and peace in Book five. These household discussions also differ from the 'verbal contest' (brahmodaya) between teachers attested in Vedic literature.

52 See, for instance, $B h G$ 4.3, when Kṛșna makes Arjuna’s being his devotee and friend the foundation as well as the motive for revealing his teaching; in the Nārāyanīya, the Brahman sage Nārada has to declare his credentials before he is instructed how to approach the god Nārāyaṇa (cf. $M B h$ 12.322).

53 See, for instance, BhG 3.31-2, where Kṛ̣na asks Arjuna to have confidence in 'my doctrine' (me matam).

54 See, for instance, $B h G 3.31,4.39-40,6.47,7.21-2,9.3,23,12.2,20$ etc. Śraddhä is one of the key terms already in Vedic literature wherein it refers to the confidence in the efficacy of Vedic rituals and becomes manifest in the willingness to pay the priests a reward for their services. In some texts, śraddhā is also used when dealing with confidence in persons of authority; see Köhler 1948, and Hacker 1963. In a number of epic texts, śraddhā is intertwined with bhakti and refers to the trust in the efficacy of the word of god and the devotion to him; see Hara 1964 and 1979 on the difference between bhakti and śraddhā. 
important feature of the promulgation of bhakti doctrines in the Mahābhärata, which highlight individualised relationships between god and devotee as the foundation of religious practice. The various ways of relating to the embodied, visible presence of an otherwise transcendent god determines the religious life of a devotee in ways that could even result in ignoring or rejecting social norms. The spectacular character of the 'vision' (darśana) of the divinity granted to the devotee in both the Bhagavadgitā and the Nārāyañiya serves to substantiate the verbal testimony by reference to empirical evidence and provides a context for god's iconic representation in places of worship. It unfolds against the background of god's presence in the human body of the teacher. The authorisation of bhakti to Vāsudeva-Kṛṣna in the Bhagavadgitā and to Viṣnu-Nārāyaṇa in the Nārāyaniyya draws on both these aspects: while its promulgation depends on a body of teachings and an embodied teacher, its authorisation draws on the criteria of the larger discourse on this issue in combining specific characteristics of their personality with the 'empirical evidence' of a theophany. Yet in both texts there are also marked attempts to realign bhakti with Vedic rituals and Brahmanical normativity. ${ }^{55}$

The acceptance of temporarily embodied 'eternal' persons as authoritative instructors is contested not only in philosophical discourse but also in the epics. It highlights the need for the new teachings to address the tension between the embodied, temporally situated, promulgation of the knowledge and the claim that it has ahistorical validity. One way to counter the Brahmanical insistence on the 'eternity' of the Veda as the reason for its insurmountable authority was to make 'eternity' or some 'transcendent' state of existence a characteristic feature of the 'trustworthy' instructor. The 'eternal' Veda is countered with the 'eternal' person (a divine or liberated being). This results in an ambiguous positioning of the 'historical' teacher as both human and divine. This may explain why there is a considerable overlap in the depictions of human-styled teachers, such as the Buddha, and the new bhakti gods appearing in a body (tanu, avatāra). ${ }^{56}$ In this

55 This can be seen in passages in the epic that aim at replacing, or at least reconnecting, the bhakti doctrines of the $B h G$ with Brahmanical norms; this tendency is already apparent in $B h G$ 17; see Malinar 2007a. In the Nārāyaṇīya, the god Nārāyaṇa is depicted as endorsing Vedic rituals and protecting the Vedic gods; for a comparison between these two texts, see Malinar 1997.

56 This is clearly formulated in the BhG 9.11ff., for instance when Kṛșna says he has taken a 'human body' in order to promulgate his divinity, while also pointing out that this should not be a reason to disrespect his tenets. It is also pointed out at $B h G$ 7.6 that the god appears in an 'apparitional' or 'artificial' body that is not subject to karman. Although the $B h G$ does not use the word avatāra, the idea of divine embodiments (the basis of what is known as the 'avatāra-doctrine') is present in the text, see Malinar 2007a. In a similar vein, Buddhism develops the 'three-body' (trikāya) doctrine of the Buddha; see Reynolds 1977. When later Nyāya philosophers like Udāya- 
way, the historically proclaimed new knowledge is turned into a manifestation of a trans-historical truth by according the teacher a transcendent, eternal state of being. A 'highest' god has to take a human body in order to reveal himself to his devotees; conversely, human teachers tend to be divinized, or are viewed as the embodiment of a transcendent state or divinity by their adherents. They show as well as represent the path to be followed. They are themselves the pramanna, the reliable authority and means of knowledge, as well as the guarantor of the efficacy of their instruction. ${ }^{57}$ In this way, the temporal quality of the statements of trustworthy persons entwines with a trans-historical truth-claim and the individualised, embodied character of its authorisation. Religious-philosophical knowledge also obtains an experiential, personal dimension, since the teacher is regarded as the living proof of the fruitfulness of practising it. His activities as attested in the stories about his life serve as corroborative evidence for the words spoken. They highlight the exceptionality, as well as the exemplariness, of the 'trustworthy person' and extend the issue of the relational structure of acceptance and persuasion to literary forms of representation (as can be seen in the emergence of the new genre of carita, 'life-history').

\section{Conclusion}

It is not being as unique or different as everybody else (and thus sharing a commonly acknowledged equality as an individual) that constitutes individuality in the sources discussed here, as is the case with modern individualism, but, rather, exceptionality and exemplariness in the realisation of a religious-philosophical knowledge, as well as skilfulness and expertise in exposing it. ${ }^{58}$ The authority of an individual can be assessed by means of a catalogue of characteristic features. In this way, exceptionality is intertwined with exemplariness as the foundation of the authority of an individual in religious matters. The combination of exemplariness and exceptionality results in an ambiguous perception. While in some respects the teacher continued to be remembered as an individual with specific

na accept the doctrine that an iśvara, a creator god or cosmic sovereign, creates the Veda, they also postulate that he has an artificial body (nirmāṇakāya) or instrument body (upakaranaśarīra) to carry out this task; see Chemparathy 1972, 148-57.

57 See $B h G 4.11$ on the god Kṛșna setting the pathway to follow and $B h G 16.24$ on his 'authoritative teaching' (śāstra) as pramāna; the teaching (dharma) promulgated by the god Nārāyaṇa in the form of an authoritative text (śāstra) is made the pramāna at $M B h 12.322 .38-41$ and 12.328.22ff. 58 See Rüpke 2013 on similar elements of individualisation in Roman antiquity in contrast to modern individualism and its emphasis on 'being different'. 
doctrines and a life-story, in other respects his very exceptionality resulted in interpretations that tended to de-individualise him. On the one hand, the emphasis on the exceptional can result in ascribing the teacher divine characteristics while, on the other, the authority of the teacher becomes part of a larger discourse on the authority of verbal testimony (śabda) in matters of the 'highest good' and 'invisible goals'. This becomes obvious in the emerging philosophical schools and their different interpretations of what constitutes the authority and validity of the statements of a person. It also marks the transition from the juxtaposition of individual 'opinions' (mati) in the Mahābhärata to the establishment of a philosophical expert discourse for dealing with 'elaborated doctrines' (mata) as the framework for evaluating such 'opinions'. Instead of recording the current confusion about what is 'best' (śreyas) by juxtaposing different views, as is done in the epic, philosophers seek to create a referential framework that authorises as well as controls pluralisation and individualisation.

All these processes are connected to contemporary socio-political contexts at different levels. The previous analysis points to the interest of supporters of new religious-philosophical ideas in endorsing individual authority and individualised religious practices. At the same time, plurality and individuals claiming authority were increasingly met with scepticism and even outright rejection by representatives of the Vedic-Brahmanical tradition, not only in the epic but also in the field of philosophy. This situation is also mirrored in a reconfiguration of the religious practices of householders in the socio-political realm and in intellectual discourse, as well as in a broadening of the social spectrum of householders engaged in the pursuit of new religious goals. Authority in matters of dharma is no longer exclusively in the hands of Brahmanical teachers, although they continue to play an important role in the epic and the (re)assertion of their authority has left its mark in many parts of the text. This connects the epic to efforts (apparently shared by both new and old religious teachers) to establish a referential framework that authorises only exceptional, highly skilful individuals in specific religious contexts and under certain conditions. While individualised forms of religious practice and individual opinions about the 'highest good' are recorded and represented in the Mahäbhärata, they are only explicitly recommended in cases of exceptional persons, who are at some point declared to be embodiments of a transcendent god (and even they do not remain uncontested in the epic). Otherwise, they are either censured - in particular in the case of women - or presented without further comments, as is the case with the Tulādhāra story. In these cases, the very inclusion of a particular instruction or religious-philosophical position in the epic is a sign of approval and authorisation by composers and redactors of the epic, as well as by patrons of manuscript production and the various audiences who constituted the pluriform ideological environment of the 
epic. ${ }^{59}$ The various doubts, opinions, and instructions included in this text thus remain accessible as modes of thinking and acting, documenting religious plurality as well as the controversies that surrounded it. ${ }^{60}$

Another aspect of the re-configuration of the household is that compliance with Vedic ritualism does not rule out personal engagement with other forms of religion or even a selective approach to the spectrum of ordained ritual duties. The interpretation of the place of Vedic rituals, for instance, for householders who have become devotees of a 'highest' personal god can take quite different forms, as the epic attests. Thus, promulgations of 'highest bhakti' that advise against worshipping other gods stand side by side with a doctrine of bhakti that includes ritual care for Vedic gods. The latter option is particularly important for householders as it allows them to continue Vedic rituals (most importantly the samskāras, so-called 'life-cycle' rituals ensuring socio-ritual status), while also adopting bhakti, or Sāṃkhya philosophy, or even Buddhism as their personal religious pathway. Yet doubting too much, or engaging in one's religious pursuit while openly rejecting social normativity, or misjudging one's competence in assessing religious accomplishments, invited censure, in particular in the case of women. Another aspect of this re-configuration is that ascetic renunciation ceases to be the only form in which one could concentrate one's life on a religious quest directed at 'liberation'. The case of the merchant Tulādhāra demonstrates that religious authority can be based on the insight that one's daily occupations are in fact the training ground for religious practice.

Pluralisation and individualisation found support in decentralised forms of patronage and an intellectual discourse that accepted authoritative texts and verbal testimony by trustworthy persons as a valid means of knowledge (pramāna). But both the epic and philosophical discourse also point to the resistance against these developments and to efforts to delimit the dynamics of such individualisation and pluralisation by restricting individual authority and individualised religiosity. The pluralisation of religious-philosophical knowledge thus resulted both in a proliferation of individualised forms of engagement with the religious field and in various attempts to restrict and delimit the latter by subjecting it to new criteria of acceptance. While this double-edged process is accompanied by what can be generalised as 'de-traditionalisation' at various

59 This is also pointed out by Bakker and Bisschop $(1999,468)$ with respect to the inclusion of various versions of Sāṃhya philosophy in the epic.

60 The recognition of these texts as a whole (but not necessarily in all of them) as authoritative is already sought in the epic itself with its claim to be the 'fifth Veda'; see Malinar 2011b. Its 'official' endorsement happens when it is regarded by advocates of the sole authority of the Veda as smrti, a text of (secondary) authority. 
levels (criticism, dissent, adoption of alternative texts and practices, turning to new teachers, etc.), it was by no means one-directional and nor did it necessarily result in a replacement of the old by the new. It led, rather, to various re-configurations of the 'transmitted knowledge' of the Veda in view of changing socio-political frameworks and a pluralised, competitive field of available religious-philosophical teachings. This may point to the fact that processes of individualisation may not only be followed by processes of de-individualisation in a later period or as resulting in more and more individualisation, but also as continuously being intertwined with groups and institutions contesting and rejecting it.

\section{References}

Bakker, Hans and Peter Bisschop. 1999. 'Mokșadharma 187 and 239-241 reconsidered', Asiatische Studien / Études Asiatiques 52.3. 459-72.

Biardeau, Madeleine. 1981. 'The Salvation of the King in the Mahābhārata', Contributions to Indian Sociology NS 15. 75-97.

Bijlert, Vittorio A. van. 1989. Epistemology and Spiritual Authority. The Development of Epistemology and Logic in the Old Nyāya and the Buddhist School of Epistemology with an annotated Translation of Dharmakīrti's Pramāṇavārttika II (Pramānasiddhi) VV.1-7. Wien: Arbeitskreis für Tibetische und Buddhistische Studien, Universität Wien.

Bloch, Jules. 1950. Les inscriptions d'Aśoka, traduites et commentées. Paris: Société d'Édition Les Belles Lettres.

Brinkhaus, Horst. 1994. 'Weltflüchtige und innerweltliche Askese im Mahābhārata'. In Zeitschrift der deutschen Morgenländischen Gesellschaft, Supplement 10: XXV. Deutscher Orientalistentag vom 8. bis 13.4.1991 in München. Vorträge, ed. Cornelia Wunsch, Stuttgart: Steiner. 273-81.

Brockington, John L. 1998. The Sanskrit Epics. Leiden: Brill.

Buitenen, J. A. B. van (ed. and trans.) 1975. The Mahābhārata: The Book of the Assembly Hall, The Book of the Forest. Chicago: Chicago University Press.

Chemparathy, George. 1972. An Indian Rational Theology: Introduction to Udāyana's Nyāyakusumāñjali. Leiden: Brill.

Chemparathy, George. 1983. L'autorité du Veda selon les Nyāya-Vaiśeșikas. Louvain-la-Neuve : Centre d'histoire des religions.

Clooney, Francis X. 1987. 'Why the Veda has no Author: Language as Ritual in Early Mīmāṃsā and Post-Modern Theology', Journal of the American Academy of Religion 55.4. 659-84.

Coningham, Robin A. E. 1995. 'Monks, Caves and Kings: A Reassessment of the Nature of Early Buddhism in Sri Lanka', World Archaeology 27.2. 222-42.

Davis, Donald R. 2004. 'Dharma in Practice: Ācāra and Authority in Medieval Dharmaśāstra', Journal of Indian Philosophy 32. 813-30.

Davis, Donald R. 2007. 'On Ātmatușți as a Source of “Dharma”', Journal of the American Oriental Society 127.3. 279-96.

Deleuze, Gilles and Félix Guattari. 1991. Qu'est-ce que la philosophie? Paris: Editions de Minuit. 
Dumont, Louis. 1960. 'World Renunciation in Indian Religions', Contributions to Indian Sociology 4. 33-62.

Dumont, Louis. 1966. Homo Hierarchicus: essai sur le système des castes. Paris: Gallimard.

Eltschinger, Vincent. 2012. 'Apocalypticism, Heresy and Philosophy'. In World View and Theory in Indian Philosophy, ed. Piotr Balcerowicz, Delhi: Manohar. 29-85.

Fitzgerald, James L. (ed. and trans.). 2004. The Mahābhärata: Book 11: The Book of Women, Book 12: The Book of Peace, Part 1. Chicago: University of Chicago Press.

Fitzgerald, James L. 2006. 'Negotiating the Shape of "Scripture": New Perspectives on the Development and Growth of the Mahābhārata between the Empires'. In Patrick Olivelle (ed.). 257-86.

Fuchs, Martin. 1988. Theorie und Verfremdung. Max Weber, Louis Dumont und die Analyse der indischen Gesellschaft. Frankfurt am Main: Lang.

Hacker, Paul. 1961. 'Zur Methode der geschichtlichen Erforschung der anonymen Sanskritliteratur des Hinduismus', Zeitschrift der Deutschen Morgenländischen Gesellschaft 111. 483-92.

Hacker, Paul. 1963. 'Śraddhā', Wiener Zeitschrift für die Kunde Süd- und Südostasiens 7. 151-89.

Härtel, Herbert. 1987. 'Archaelogical Evidence on the Early Vāsudeva Worship'. In Orientalia: Iosephi Tucci memoriae dicata 2, ed. Gherardo Gnoli, Rome: Istituto italiano per il Medio ed Estremo Oriente. 573-87.

Halbfass, Wilhelm. 1991. Tradition and Reflection. Explorations in Indian Thought. Albany: State University of New York Press.

Hara, Minoru. 1964. 'Note on Two Sanskrit Religious Terms: bhakti and śraddhä', Indo-Iranian Journal 7.2/3.124-43.

Hara, Minoru. 1979. 'Śraddhāviveśa', Indologica Taurenensia 7. 261-73.

Holtzmann, Adolf. 1892-95. Das Mahābhārata und seine Theile. 4 vols. Kiel: Haeseler.

Hopkins, Edward W. 1902. The Great Epic of India. Its Character and Origin. New York: Scribner.

Johnston, Edward H. (ed. and trans.). 1984. The Buddhacarita or, Acts of the Buddha. 2 parts. Delhi: Motilal Banarsidass.

Kloppenburg, Ria. 1983. A Study of the Concept of the Paccekabuddha in Pali Canonical and Commentarial Literature. Kandy: Buddhist Publication Society.

Krasser, Helmut. 2001. 'On Dharmakīrti’s Understanding of pramānabhūta and his Definition of pramāṇa', Wiener Zeitschrift für die Kunde Südasiens 45.173-99.

Köhler, Hans-Werbin. 1948. śrad-dha in der vedischen und altbuddhistischen Literatur. Thesis. Göttingen.

Lamotte, Etienne. 1958. Histoire du Bouddhisme Indien des origines à l'ère Śaka. Louvain: Peeters.

Mahābhārata. 1933-59. The Mahābhārata for the First Time Critically Edited by a Board of Scholars. 19 vols. Poona: Bhandarkar Oriental Research Institute.

Malinar, Angelika. 1997. 'Nārāyaṇa und Kṛṣna: Aspekte der Gotteslehre des Nārāyaṇīya im Vergleich zur Bhagavadgītā'. In Peter Schreiner (ed.). 241-95.

Malinar, Angelika. 2007a. The Bhagavadgītā: Doctrines and Contexts. Cambridge: Cambridge University Press.

Malinar, Angelika. 2007b. 'Arguments of a Queen: Draupadīs Views on Kingship'. In Epic Constructions: Gender and Narrative in the Mahābhārata, eds. Brian Black and Simon Brodbeck, London: Routledge. 79-96. 
Malinar, Angelika. 2011a. “Vom “Kanon-Fundus” zum “variablen Kanon”: Über den Status religiöser Texte im Hinduismus'. In Kanonisierung und Kanonbildung in der asiatischen Religionsgeschichte, eds. Max Deeg, Oliver Freiberger and Christoph Kleine, Wien: Verlag der Österreichischen Akademie der Wissenschaften. 57-80.

Malinar, Angelika. 2011b. 'Vier Veden und der "fünfte Veda”. Über Kanonbildung im Hinduismus'. In Kanon und Kanonisierung: Ein Schlüsselbegriff der Kulturwissenschaften im interdisziplinären Dialog, eds. Karénina Kollmar-Paulenz et al., Basel: Schwabe. 182-211.

Malinar, Angelika. 2012. 'Worte als Erkenntnismittel: Über die Autorität von Texten in der indischen Philosophie'. In Texte und Autoritäten: Autorität der Texte, ed. Paolo Becci et al., Basel: Schwabe. 126-52.

Malinar, Angelika. 2014. “'Following one’s Desire” (kāmacāra): On a Characterisation of Freedom in Vedic literature and the Mahābhārata', Asiatische Studien / Études Asiatiques 68.4. 757-82.

Malinar, Angelika. 2015a. 'Religious Pluralism and Processes of Individualization in Hinduism', Religion 45.3. 386-408.

Malinar, Angelika. 2015b. 'Nārada and the Pāṇḍavas: Regulating Domestic Life in the Mahābhārata'. In In her right hand she held a silver knife with small bells.... Studies in Indian Culture and Literature, eds. Anna A. Esposito et al., Wiesbaden: Harrassowitz. 157-76.

Malinar, Angelika. 2017a. 'Philosophy in the Mahābhārata and the History of Indian Philosophy', Journal of Indian Philosophy 45.4. 587-604.

Malinar, Angelika. 2017b. 'Narrating Sāṃkhya Philosophy: Bhīṣma, Janaka and Pañcaśikha at Mahābhārata 12.211-12', Journal of Indian Philosophy 45,4: 609-649.

Malinar, Angelika. 2019. 'India'. In Handbook of Autobiography / Autofiction, Vol. 2: History of Autobiography, ed. Martina Wagner-Egelhaaf. Berlin: de Gruyter, 967-984.

Matilal, Bimal K. 1986. Perception. An Essay on Classical Indian Theories of Knowledge. Oxford: Oxford University Press.

Oberhammer, Gerhard. 1974. 'Die Überlieferungsautorität im Hinduismus'. In Offenbarung: Geistige Realität des Menschen. Arbeitsdokumentation eines Symposiums zum Offenbarungsbegriff in Indien, ed. idem, Wien: Indologisches Institut der Universität Wien. 41-92.

Olivelle, Patrick. 1993. The Āśrama System: History and Hermeneutics of a Religious Institution. New York/Oxford: Oxford University Press.

Olivelle, Patrick (ed.). 2006. Between the Empires. Society in India 300 BCE to 400 CE. Oxford: Oxford University Press.

Proudfoot, Ian. 1979. 'Interpreting Mahābhārata Stories as Sources for the History of Ideas', Annals of the Bhandarkar Oriental Research Institute 60. 41-63.

Reynolds, Frank E. 1977. 'The Several Bodies of the Buddha: Reflexions on a Neglected Aspect of the Theravāda Tradition', History of Religion 16. 374-89.

Ruegg, David S. 1994. “'Pramāṇabhūta, *pramāṇa (bhūta)-puruṣa, pratyakșadharman' and "sākṣātkṛtadharman" as Epithets of the "ṛ̣ị, ācārya” and "tathāgata” in Grammatical, Epistemological and Madhyamaka Texts', Bulletin of the School of Oriental and African Studies, University of London 57.2, 303-20.

Ruegg, David S. 1995. 'Validity and Authority or Cognitive Rightness and Pragmatic Efficacy? On the Concepts of pramāṇa, pramāṇabhūta and pramāṇa(bhūta)puruṣa',Asiatische Studien 49. 817-27. 
Rüpke, Jörg. 2013. 'Individualization and Individuation as Concepts for Historical Research'. In The Individual in the Religions of the Ancient Mediterranean, ed. idem, Oxford: Oxford University Press. 3-40.

Saksena, Sushil K. 1951. 'Authority in Indian Philosophy', Philosophy East and West 1.3. 38-49. Schreiner, Peter (ed.). 1997. Nārāyañīya-Studien. Wiesbaden: Harrassowitz.

Silk, Jonathan A. 2002. 'Possible Indian Sources for the Term "tshad ma'i skyes bu" as “pramānapuruṣa”, Journal of Indian Philosophy 30.2. 111-60.

Strauss, Otto. 1911. 'Ethische Probleme aus dem Mahābhārata', Giornale della Societa Asiatica Italiana 24. 193-335.

Sutton, Nicholas. 2000. Religious Doctrines in the Mahābhārata. Delhi: Motilal Banarsidass.

Taber, John. 1992. 'What did Kumārila Bhațța mean by Svataḥ Prāmāṇya?', Journal of the American Oriental Society 112.2. 204-21.

Tarkatirtha, Taranatha Nyaya and Amarendramohan Tarkatirtha (eds.). 1985. Nyāyasūtra: Nyāyadarśanam with Vātsyāyana's Bhāṣya, Uddyotkara's [sic!] Vārttika, Vācaspati Miśra's Tātparyațīkā \& Viśvanātha's Vrttti. Delhi: Munshiram Manoharlal.

Thapar, Romila. 1961. Aśoka and the Decline of the Mauryas. Oxford: Oxford University Press. Willis, Janice D. 1992. ‘Female Patronage in Indian Buddhism'. In The Powers of Art. Patronage in Indian Culture, ed. Barbara Stoler Miller, Oxford: Oxford University Press. 46-53.

Yuktidīpikā. 1998. Yuktidīpikā: the most significant Commentary on the Sāṃkhyakārikā: critically edited, ed. by A. Wezler and S. Motegi. Stuttgart: Steiner. 